\title{
Flow Activation Volume and Lubricity of Polymer-blended Oil as a Rolling Fluid
}

\author{
Yasukatsu Tamai*1), Masataka Mizoguchi*2), Koe Nakajima*3) and Yoshiki Shibata*3)
}

\begin{abstract}
Light mineral oil was blended with methacrylate polymers to suitable viscosities for cold rolling of steel. The flow activation volume of the blended oils was measured and investigated in comparison with frictional characteristics under sliding-rolling conditions. The performance of the oils was also examined with a laboratory mill up to $2,000 \mathrm{~m} / \mathrm{min}$ with good results.
\end{abstract}

\section{Introduction}

It is well known that fatty oil, especially palm oil, is one of the best lubricants for cold rolling of steel to produce thin plates. This superior performance is considered to be due to the oiliness of the free fatty acid in the oil. However, the effectiveness of the fatty acid is not so clear-cut, if judged from the following instances. Carbon steel was rolled under the conditions of single pass and reduction of $16.5 \%$ with a paraffinic mineral oil lubricant and the same containing 1\% stearic $\operatorname{acid}^{1}$. Their coefficients of friction were found to be 0.080 and 0.075 , respectively, showing a very small difference as compared with the results 0.18 and 0.10 for the above mentioned two lubricants, obtained with a conventional boundary lubricity tester such as friction pendulum.

This fact suggests the importance of thin oil film lubrication in steel rolling. One of the aims of this study was to investigate the role of viscosity in cold rolling of steel. As a parameter of highpressure viscosity, the flow activation volume was measured by Eyring's theory for several lubricants, and its relation to lubricity in sliding rolling friction was examined. Another aim was to develop a fluid suitable for rolling utilizing the guiding principle of activation volume. A polymer-blended oil was tested with a laboratory mill which was operated at rolling speeds up to $2,000 \mathrm{~m} / \mathrm{min}$.

Received Aug. 21, 1978.

This is Part V of Rheological Studies of Lubricating Oils

*1) Chemical Research Institute of Nonaqueous Solutions, Tohoku University (2-1-1, Katahira, Sendai 980)

*2) Fujikura Kasei Co., Ltd. 2-6-15, Shiba-koen, Minatoku, Tokyo 105)

*3) Process Technology Research and Development Laboratories, Nippon Steel Corp. (1-1-1, Edamitsu, Yawatahigashi-ku, Kitakyushu 805)

\section{Measurement of Flow Activation Volume}

\subsection{Test Oils}

Two groups of oils were investigated. One group was polymer-blended oils, and the other was representative rolling fluids. Their viscosities were in the same range-about $120 \mathrm{cSt}$ at $25.0^{\circ} \mathrm{C}$.

Polymethacrylates of stearyl (S), tridecanoyl $(\mathrm{T})$, and lauryl (L) alcohols were used. These polymer esters were blended with a light paraffinic mineral base oil (viscosity : $5.4 \mathrm{cSt}$ at $25^{\circ} \mathrm{C}, 3.1$ cSt at $50{ }^{\circ} \mathrm{C}$ ). They are listed in Table 1 , where $\mathrm{SL}$, for example, indicates a methacrylate polymer consisting of both stearyl and lauryl esters, and SL8/ST2 means a mixture of SL polymer $(80 \%)$ and ST polymer $(20 \%)$. The average molecular weight of the polymer was different for each case, higher in oil No. 2 than in oil No. 1. As a reference oil, oil No. 6 was prepared by blending the light mineral oil with paraffinic bright stock (viscosity : $123.8 \mathrm{cSt}$ at $25^{\circ} \mathrm{C}$ ).

Another group included a vegetable oil (oil No. 7) and a synthetic ester (oil No. 8), pentaerythrytol tetraoleate (viscosity : $120.7 \mathrm{cSt}$ at $25^{\circ} \mathrm{C}$ ). The vegetable oil was a blend of castor oil and olive oil in a weight ratio of 3 to 7 (viscosity : 117.3 cSt at $25^{\circ} \mathrm{C}$ ).

\subsection{High Pressure Viscosity and Density}

As has been reported previously'), to obtain flow activation volume, it is necessary in the present study to measure both viscosity and density at high pressure $-300 \mathrm{~atm}$. The activation volume,

Table 1 Polymer-blended Oils

\begin{tabular}{c|ccc}
\hline $\begin{array}{c}\text { Oil } \\
\text { No. }\end{array}$ & Polymer & $\begin{array}{c}\text { Blend } \\
(\%)\end{array}$ & $\begin{array}{c}\text { Viscosity } \\
\left(\mathrm{cSt}, 25^{\circ} \mathrm{C}\right)\end{array}$ \\
\hline 1 & SL & 21 & 120.7 \\
2 & SL & 13 & 125.9 \\
3 & L & 71 & 114.5 \\
4 & SL8/ST2 & 15 & 121.3 \\
5 & ST & 21 & 118.6 \\
\hline
\end{tabular}


Table 2 Viscosity and Density

\begin{tabular}{c|cccc}
\hline Oil & $\eta_{\mathbf{1}}$ & $\rho_{\mathbf{1}}$ & $\eta_{\mathbf{3 0 0}}$ & $\rho_{\mathbf{3 0 0}}$ \\
\cline { 1 - 5 } 1 & 100.4 & 0.8322 & 164.7 & 0.8465 \\
2 & 103.0 & 0.8215 & 166.0 & 0.8392 \\
3 & 99.74 & 0.8883 & 181.0 & 0.9064 \\
4 & 100.3 & 0.8372 & 161.9 & 0.8389 \\
5 & 98.41 & 0.8298 & 161.3 & 0.8416 \\
6 & 104.9 & 0.8475 & 199.4 & 0.8640 \\
7 & 108.3 & 0.9227 & 175.1 & 0.9342 \\
8 & 110.8 & 0.9195 & 171.6 & 0.9331 \\
\hline
\end{tabular}

$\Delta V^{\ddagger}$, is calculated from the following equation :

$$
\Delta V^{\ddagger}=R T \frac{\mathrm{l}_{\mathrm{n}} \nu_{1}-\mathrm{l}_{\mathrm{n}} \nu_{300}}{p_{1}-p_{390}} \quad \nu=\frac{\eta}{\rho}
$$

where $R$ is the gas constant, $T$ absolute temperature, $v$ kinematic viscosity, $p$ pressure, $\eta$ viscosity, and $\rho$ density. Subscripts 1 and 300 mean 1 and 300 atm, respectively. Viscosity was measure with a rolling-ball viscometer and density with a piezometer, both at $25.0 \pm 0.1{ }^{\circ} \mathrm{C}$ within $\pm 1 \%$ accuracy. The results are summarized in Table 2, where viscosity and density are given in $\mathrm{cP}$ and $\mathrm{g} / \mathrm{cm}^{3}$, respectively.

\subsection{Galculated Activation Volume}

From the above equation, $\Delta V^{\ddagger}$ can readily be calculated, and the results are shown in Table 3. The smallest value is for pentaerythrytol ester and the largest for the mineral oil. Oils No. 1 and No. 2 are blends of the same type of polymers but differing in the amount blended and degree of polymerization. However, the $\Delta V^{\ddagger}$ values are nearly equal, suggesting a mechanism of segment flow at the molecular level.

Table 3 Flow Activation Volume

\begin{tabular}{ll|c}
\hline \multicolumn{1}{|c|}{ Oil } & $\Delta \mathrm{V} \neq\left(\mathrm{cm}^{3} / \mathrm{mol}\right)$ \\
\hline 1 & PSLMA 21 & 38.5 \\
2 & PSLMA 13 & 37.2 \\
3 & PLMA & 46.6 \\
4 & PSLMA/PSTMA & 37.4 \\
5 & PSTMA & 38.7 \\
6 & Mineral Oil & 50.8 \\
7 & Vegetable Oil & 37.8 \\
9 & Synthetic Ester & 34.6 \\
\hline
\end{tabular}

\section{Measurement of Lubricity in Sliding- Rolling}

\subsection{Friction Device}

The friction device used was similar to the SAE friction machine. Two bearing-steel rings were made of high chromium bearing steel, in identical shape of $4 \mathrm{~cm}$ in diameter, $12 \mathrm{~mm}$ in width, and the face curved with a radius of $60 \mathrm{~cm}$. They could be rotated separately, and were pressed together with a spring. Oil was supplied through an oil-containing sponge lightly contacting with

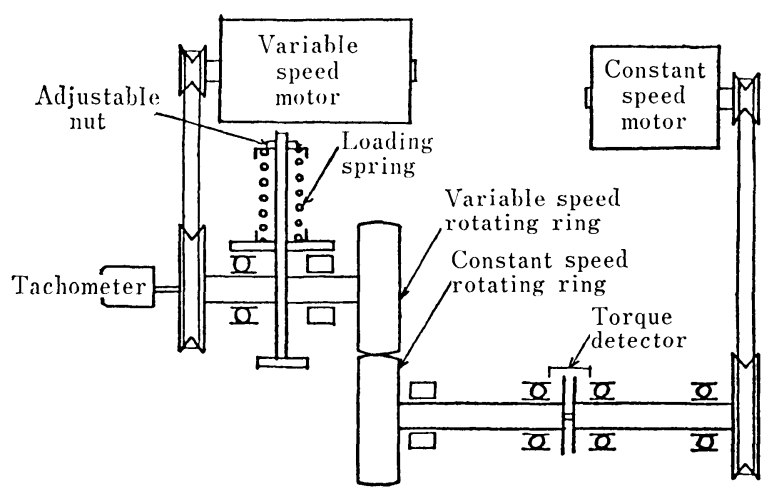

Fig. 1 Rolling-Sliding Friction Machine

the two rotating rings. A schematic drawing of the device is given in Fig. 1.

Friction was measured electronically from the phase shift between the rotating shaft and its driving shaft both of which were connected with a torsion bar.

\subsection{Friction Measurement}

Details of measuring procedures are described elsewhere ${ }^{3)}$. In short, prior to the measurement, run-in was made with a light load but at predetermined sliding-rolling, and then the applied load was increased up to the desired level. Steady friction was observed after 2 or $3 \mathrm{~min}$. After the test, the friction trace was examined to ascertain that no seizure had occurred under the testing conditions.

Conditions for measurements were fixed at a rolling speed of $27 \mathrm{~m} / \mathrm{min}$ for one ring and $87 \mathrm{~m} / \mathrm{min}$ for the other that resulted in a sliding speed of $1 \mathrm{~m} / \mathrm{sec}$. The applied load was usually $150 \mathrm{~kg}$ which corresponded to the average contact pressure of $64 \mathrm{~kg} / \mathrm{mm}^{2}$. Measurements were made at room temperature.

The results of friction coefficient, $f$, are shown in Table 4 for the polymer-blended oils and the bright stock blended oil; the oils are arranged in order of increasing $\Delta V^{\ddagger}$.

From this table, oil No. 5 seemed best among the polymer-blended oils. This oil was compared with a vegetable oil and a synthetic ester under a severer condition of $200 \mathrm{~kg}$ load $(82 \mathrm{~kg} /$ $\mathrm{mm}^{2}$ ). The results in Table 5 indicate that oil

Table 4 Lubricity $f$ Blended Oils

\begin{tabular}{ll|c}
\hline \multicolumn{1}{|c|}{ Oil } & $f$ \\
\hline 2 & PSLMA 13 & 0.071 \\
4 & PSLMA/PSTMA & 0.073 \\
1 & PSLMA 21 & 0.070 \\
5 & PSTMA & 0.067 \\
3 & PLMA & 0.086 \\
6 & Bright Stock & 0.083 \\
\hline
\end{tabular}


Table 5 Comparison of Rolling Oils

\begin{tabular}{l|cl}
\hline \multicolumn{1}{c|}{ Oil } & $f(150 \mathrm{~kg})$ & $f(300 \mathrm{~kg})$ \\
\hline Vegetable Oil & 0.067 & $0.067 \sim 0.069$ \\
Synthetic Ester & 0.064 & $0.064 \sim 0.065$ \\
PSTMA 21\% Oil & $0.067 \sim 0.068$ & $0.026 \sim 0.067$ \\
\hline
\end{tabular}

No. 5 is almost equivalent to these rolling fluids.

\section{Relation between Lubricity and Flow Activation Volume}

As mentioned in the introduction, there may be a hydrodynamic oil film at friction contact in the sliding-rolling experiment, and a relation between $f$ and $\Delta V \neq$ may exist. In Fig. $2, f$ is plotted against $\Delta V \neq$ for all the fluids examined. It is evident that increasing $\Delta V^{\neq}$results in increasing $f$; in other words, larger viscosity at higher pressure makes traction greater. This relation may hold, with certain limitations, that viscosities of the oils are at the same level.

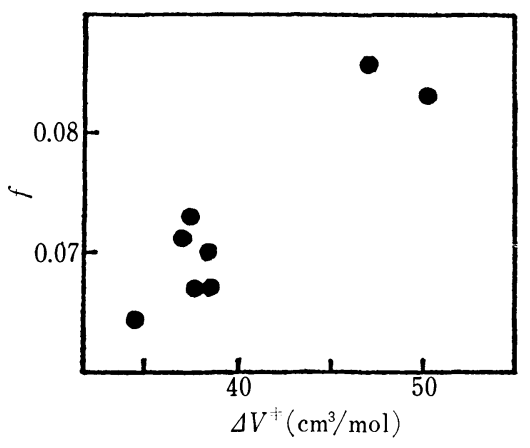

Fig. 2 Relation between $f$ and $\Delta V \neq$

\section{Laboratory Mill Test}

\subsection{Rolling Performance}

A high-speed laboratory test mill constructed by Nippon Steel Corporation was used. The working roll was bright finish, $400 \mathrm{~mm}$ in diameter, and $100 \mathrm{~mm}$ in width.

Oil No. 5, the best polymer-blended oil, and palm oil were tested. A $1.8 \times 50 \times 100 \mathrm{~mm}$ sheet of low carbon steel was cold rolled at a reduction of $20 \%$ and at various speeds from 250 to $1,000 \mathrm{~m} /$ min. The oil was applied as a precoated thin film on the test steel specimen in various thicknesses of 0.2 . $0.5,1.0$, and $2.0 \mathrm{~g} / \mathrm{m}^{2}$. The necessary load was measured and shown in Fig. 3, where the abscissa is the amount of the coated.

When only a smaller amount of oil was applied, the roll load was larger with polymer-blended oil, but when a sufficient amount was applied, it was almost the same as that of palm oil. Interestingly, the load is smaller at $1,000 \mathrm{~m} / \mathrm{min}$

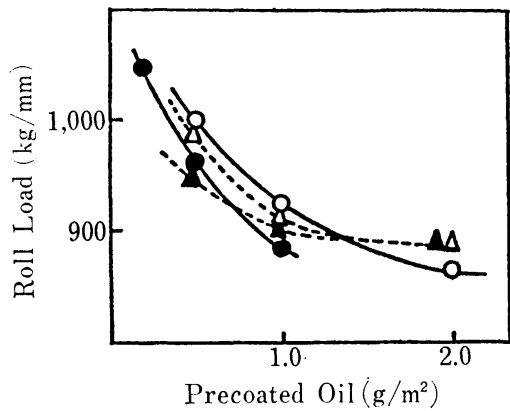

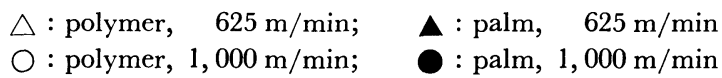

Fig. 3 Roll Load and Oil Amount

than at $625 \mathrm{~m} / \mathrm{min}$. This may be due to a higher temperature rise, that reduces the viscosity of the oil at rolling contact, and/or due to a thicker hydrodynamic oil film which reduces both the shear rate and probable metallic contact.

\subsection{Oil Film Thickness}

Oil film thickness between the roll and strip was measured at higher rolling speeds. Low-carbon steel strip of $1.0 \mathrm{~mm}$ thickness was cold rolled at various speeds at $30^{\circ} \mathrm{C}$ and the reduction was $20 \%$. The oils examined were oil No. 5 and a commercial rolling fluid. The oil tested was not precoated on the whole surface but only on the square area of $30 \times 33 \mathrm{~mm}$, the front side of which was perpendicular to the rolling direction as shown in Fig. 4. The weight of the precoated oil was measured. After rolling, the square shape was deformed and spread into a bulletshaped area which was measured, and the mean thickness of the oil was calculated by dividing the amount of oil by the bullet-shaped area. The results are shown in Fig. 5.

The behavior of the two tested oils was quite different from each other. The thickness of the commercial fluid increased at lower speeds and

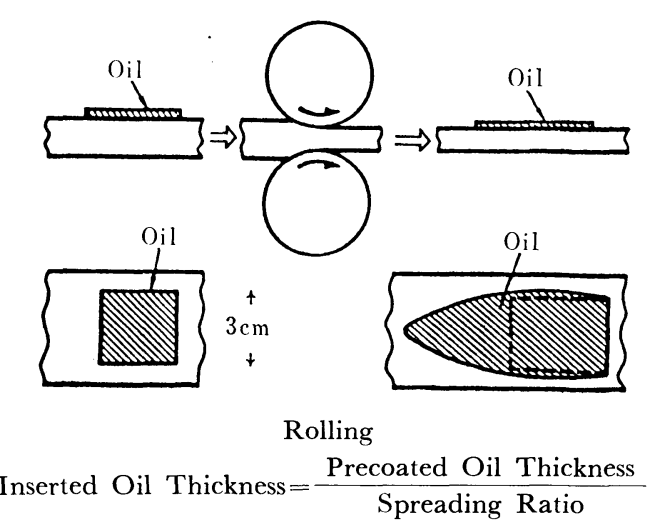

Fig. 4 Film Thickness Measurement 


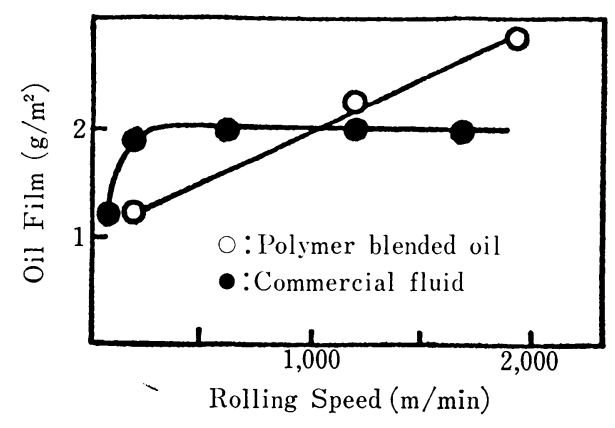

Fig. 5 Oil Film Thickness after Rolling

was almost constant at speeds higher than 250 $\mathrm{m} / \mathrm{min}$. In contrast, the thickness of oil No. 5 increased linearly up to $2,000 \mathrm{~m} / \mathrm{min}$.

According to a simple hydrodynamic theory, the oil thickness should be proportional to the rolling velocity, provided that viscosity and shape of the solid elements are unchanged. However, the observed behavior of the commercial fluid is normal in rolling practice, and it is explained by such factors as temperature rise, viscosity decrease, and so forth at higher speeds. The behavior of the polymer-blended oil is rather strange. The reason may be rheological, but at present no adequate explanation can be given.

\section{Conclusion}

In the development of rolling oils, a series of polymer-blended, thin mineral oil type fluids were studied from the theoretical standpoint of flow activation volume and they were also examined by use of a high-speed laboratory mill. A polystearyl-tridecanoyl-methacrylate blended low viscosity paraffinic oil was found promising in the sense that the rolling performance was comparable to that of palm oil. The strange behavior of increasing oil thickness with higher rolling speed was, indeed, favorable. Practical application tests of polymerblended oils on an industrial scale are now in progress.

\section{References}

1) Cockroft, M. G., "Lubrication in Metal-Working", Braithwaite, E. R., ed., 498 (1976) Elsevier Publishing Co., Amsterdam.

2) Tamai, Y., Yoneda, T., Bull. Japan Petrol. Inst., 18, (1), 9 (1976).

3) Moniwa, Y., Naka, R., Tamai, Y., Junkatsu, 17, (5), 297 (1972). 


\title{
圧延油用高分子混合油の流動活性化体積と潤滑性
}

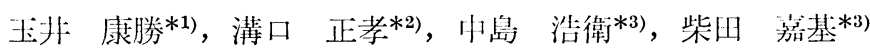

鉄鋼薄板の冷間圧延油として油脂が良好な性能を示すことは 周知であるが，その理由として上げられる遊離脂肪酸の油性 は, 純パラフィン油と脂肪酸添加パラフィン油の実験ミルでの 性能にほとんど差がないことから, 必ずしも十分でなく, 油膜 潤滑の可能性が強い。そこで数種の油について高圧粘性の指標 である流動活性化体積 $\Delta V$ キを測り，こるがりーすべり試験機 に上る摩擦係数 $f$ との関連を求め, その結果良好な性能を示し た高分子混合油については $2,000 \mathrm{~m} / \mathrm{min}$ の高速運転圧延試験 を行い, 圧延荷重, 油膜厚について油脂同等あるいはそれ以上 の性能をもつことを明らかにした。

高分子はメタクリレートでフルコールはステアリル，トリデ カノイル, ラウリルの純あるいは 2 成分エステルであり, 分子 量も異なるものを低粘度パラフィン油に 13 21\% 混合して試 油とした。対比のため植物油脂, ペンタェリスリトールェステ ル，パラフィン油とブライトストックの混合油も試験した。粘

*1) 東北大学非水溶液化学研究所（980 仙台市片平 2-1-1）

*2) 藤倉化成株式会社

*3）新日本製鉄株式会社
度は $25^{\circ} \mathrm{C}$ で $120 \mathrm{cSt}$ に調製してある(Tables 1, 2)。

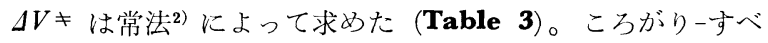
り試験機は SAE マシン類似のもので3)，2 円筒（ベアリング 鋼, 径 $4 \mathrm{~cm}$, 面曲率 $60 \mathrm{~cm}$ ) のころがり速度は 27 および 87 $\mathrm{m} / \mathrm{min}$, すべり速度 $1 \mathrm{~m} / \mathrm{sec}$, 接触荷重は $150 \mathrm{~kg}\left(64 \mathrm{~kg} / \mathrm{mm}^{2}\right)$ および $200 \mathrm{~kg}\left(82 \mathrm{~kg} / \mathrm{mm}^{2}\right)$ であり, 給油はパッドで行った。 $f$ は 0.064 から 0.086 の間に入り, 大体 $\Delta V \neq$ 之直線関係 にあり， $\Delta V \neq$ が小さい程 $f$ は小さ (Tables 4, 5, Fig. 2)。 高分子混合油の中の最良のものは油脂に劣らず，高速試験压延 機でパーム油との性能比較を行った。 $1.8 \mathrm{~mm}$ の軟鋼板を圧延 速度 625 および $1,000 \mathrm{~m} / \mathrm{min}$ で油塗布量を $0.2 \sim 2.0 \mathrm{~g} / \mathrm{m}^{2}$ に 変えて圧下率 $20 \%$ のときの圧延荷重を測った結果, $1,000 \mathrm{~m} /$ min では十分給油すると高分子混合油はパーム油と同等であ ることが判った (Fig. 3)。また同試験機でロールと鋼板にはさ まれる油膜厚を測ったところ (Fig. 4), 市販圧延油は $250 \mathrm{~m} /$ min まで増大しそれ以上では一定となるのに，高分子混合油 は高速ほど厚くなった (Fig.5)。この現象のレオロジー的説明 はまだできないが，高分子混合油は有望であり実験テストが計 画されている。

\section{Keyword}

Flow activation volume, Lubricity, Oil film, Polymer blended oil, Rolling fluid 